\title{
Synthesis and Characterization of Some Azo-heterocycles Incorporating pyrazolopyridine Moiety as Disperse Dyes
}

\author{
Hatem E. Gaffer and Tawfik A. Khattab* \\ Dyeing, Printing and Auxiliaries Department, Textile Research Division, National \\ Research Centre, Cairo 12622, Egypt.
}

\begin{abstract}
TN THIS research paper, we used 3-aminopyrazolo[3,4-b]pyridine as key intermediate for the synthesis of some pyrazolopyridine azo compounds. The key starting fused heterocyclic 3-aminopyrazolo[3,4-b]pyridine is prepared by the reaction of 2-chloro4,6-dimethylnicotinonitrile with hydrazine hydrate. The azo-coupling reaction of the pyrazolopyridinyl diazonium salt with a variety of coupling agents such as $\beta$-naphthylamine, $\beta$-naphthol, thiazole, and aniline derivatives afforded the corresponding arylazopyrazolo[3,4- $b$ ] pyridine derivatives in relatively high yield. The chemical structures were established using FTIR, elemental analysis (C, H, N), and ${ }^{1} \mathrm{H}-\mathrm{NMR},{ }^{13} \mathrm{C}-\mathrm{NMR}$. The prepared arylazopyrazolo[ $[3,4-b]$ pyridine disperse dyes were applied to dye polyester garments to provide good color fastness properties.
\end{abstract}

Keywords: Aminopyrazolo[3,4- $b]$ pyridine, Azo-coupling, Arylazopyrazolo[3,4- $b]$ pyridine, Disperse dyes. Dyeing polyester.

\section{Introduction}

Nitrogen-containing heterocyclic compounds are a valuable class of materials because of their interesting biological characteristics as pharmacophores of extensive historical significance [1-5]. 1H-pyrazolo[3,4-b] pyridines especially comprise an attractive group of compounds due to their considerable and varied biological and pharmacological applications such as anti-malarial [6], anti-proliferative [7], antibacterial [8], kinase-inhibitor [9], cardiovascular [10], anti-viral [11], and anti-leishmanial medications [12]. Fused heterocycles such as pyrazolopyridines and pyrazolopyrimidines are well known to own a broad spectrum of biological activity. Specifically, pyrazolopyridines demonstrate anti-tubercular and anti-anxiety medical properties [13]. Furthermore, such fused heterocyclic compounds have been used as dyes for textile coloration $[2,5]$. The biological activity received recently a very high attention from researcher due to the increased antimicrobial resistance developed by significant microorganisms [14]. In addition, emerging and reemerging microbial infections diseases still lead to global death and disability [15]. In view of the aforementioned findings and as continuation of our effort to discover new candidates that may be of importance in designing novel effective and selective anti-microbial material drugs, we report herein the preparation of some arylazo heterocycles incorporating pyrazolopyridine moiety starting from 3-aminopyrazolo [3,4-b] pyridine in order to investigate their spectral characteristics. Such water-insoluble and small molecular arylazopyrazolopyridine compounds can be utilized as disperse dyes able to potentially dye hydrophobic fabrics.

\section{Experimental}

\section{Materials and methods}

All melting points (uncorrected) are in degree centigrade and were determined on Gallenkamp electric melting point apparatus. Elemental analyses were carried out in the microanalytical unit, Faculty of Science, University of Mansoura IR spectra were recorded $(\mathrm{KBr})$ with on a Mattson 5000 FTIR spectrometer. ${ }^{1} \mathrm{H}$ NMR spectra were measured on a Bruker WP 300 in deuterated DMSO as solvent, using TMS as an internal standard at $295^{\circ} \mathrm{K}$. The color strength was tested using an UltraScan PRO Spectrophotometer (light source D65/10 observer). Solvents used in this study were obtained from Fluka and Aldrich. All reactions were monitored by thin layer chromatography (TLC) using Merck aluminum plates pre-coated with silica gel PF254; 20-20, 0.25

*Corresponding author e-mail: ta.khattab@nrc.sci.eg

DOI : 10.21608/ejchem.2017.1480.1104

C2017 National Information and Documentation Center (NIDOC) 
$\mathrm{mm}$, and detected by visualization of the plate under UV lamp (254 or $365 \mathrm{~nm}$ ). Compounds were purified through recrystallization or using flash column chromatography which was performed on Scharlau silica gel, packed by the slurry method. Scoured and bleached 100\% polyester fabrics were supplied by El-Mahalla El-Kobra Company, El-Mahalla, Egypt.

\section{Dyeing procedure}

The dyeing process was performed on polyester fibers via high temperature dyeing method by dispersing proper amount of dye ( $2 \%$ shade) in $1 \mathrm{~mL}$ DMF and then added dropwise with stirring to the dye-bath (liquor ratio 50:1) containing sodium lignin sulfonate as dispersing agent (ratio of dispersing agent to dye is 1:1). The $\mathrm{pH}$ of the dye-bath is kept at $\sim 4.85$ employing aqueous acetic acid and the wettedout polyester samples are added. The dyeing procedure was accomplished by increasing the dye-bath temperature to $130^{\circ} \mathrm{C}$ for 180 minutes under pressure in an infra-red dyeing machine. After dyeing, the polyester samples are rinsed followed by surface reduction clearing in a solution composed of ( $(2 \mathrm{~g} \mathrm{NaOH}+2 \mathrm{~g}$ sodium hydrosulphite)/L, and soaped with $2 \%$ nonionic detergent) for 45 minutes at $80^{\circ} \mathrm{C}$. Wash well in cold water and neutralize with $1 \mathrm{~g} / \mathrm{L}$ acetic acid for 5 minutes at $40^{\circ} \mathrm{C}$, followed by rinsing under tap water and dried at ambient temperature [16].

\section{Color strength and fastness measurements}

Fastness to wash, rubbing, perspiration and light were tested according to standard dyeing ISO methods [17-20]. The color strength of the dyed polyester samples expressed as K/S was assessed by the high reflectance method [21].

\section{Synthetic approaches}

Synthesis of 3- amino- 4,6- dimethyl- $1 H$ pyrazolo [3,4-b] pyridine 1

The key starting material 3- aminopyrazolo [3,4-b]pyridine 1 could be prepared by the reaction of 2-chloro-4,6-dimethylnicotinonitrile with hydrazine hydrate. Its versatility derives from the easy access of 2-chloro-4,6dimethylnicotinonitrile from condensation reaction of acetyl acetone and cyanoacetamide [22-25]. m.p. $276-277^{\circ} \mathrm{C}$, lit. m.p. $272-273^{\circ} \mathrm{C}$. IR $\left(\mathrm{v} / \mathrm{cm}^{-1}\right): 3388,32387,3188\left(\mathrm{NH}_{2}, \mathrm{NH}\right)$ and 1630 $\mathrm{cm}^{-1}(\mathrm{C}=\mathrm{N}) .{ }^{1} \mathrm{H}$ NMR $\left(\mathrm{DMSO}_{6}\right): \delta / \mathrm{ppm} 2.40(\mathrm{~s}$, $\left.3 \mathrm{H}, \mathrm{CH}_{3}\right), 2.50\left(\mathrm{~s}, 3 \mathrm{H}, \mathrm{CH}_{3}\right), 5.05\left(\mathrm{~s}, 2 \mathrm{H}, \mathrm{NH}_{2}\right)$, 6.60 (s, 1H, pyridine $\mathrm{C}-5), 11.65(\mathrm{~s}, 1 \mathrm{H}, \mathrm{NH}) .{ }^{13} \mathrm{C}$ NMR (DMSO-d $)$ ): $\delta / p p m ~ 18.27,24.04,104.16$, $115.48,142.21,148.14,152.85,157.41$.

Egypt.J.Chem. Special Issue (2017)
Synthesis of 5- (2- (4,6-dimethyl-1H-pyrazolo [3,4-b]pyridin-3-yl) diazenyl)- N-substituted-4phenylthiazol-2-amine 4

Sodium nitrite solution $(0.69 \mathrm{~g}, 10 \mathrm{mmol})$ was added dropwise with stirring during $15 \mathrm{~min}$. to an ice-cooled sample of compound 1 (1.62 g, 10 $\mathrm{mmol})$ at $0-5^{\circ} \mathrm{C}$, dissolved in concentrated $\mathrm{HCl}$ $(3 \mathrm{ml})$ and water $(2 \mathrm{ml})$. At the end of addition, the stirring was continued for further $15 \mathrm{~min}$. To a cold solution of phenylthiazoleamine derivatives $3 \mathrm{a}-\mathrm{c}(0.01 \mathrm{~mol}$ of each) in acetic acid $(30 \mathrm{ml})$, the diazonium salt solution $2(0.01 \mathrm{~mol})$ was added dropwise with stirring. Stirring was continued for 2 hours. The products so formed were collected by filtration and washed with water followed by cold ethanol. The isolated compounds were recrystallized from ethanol to give the corresponding heteroarylazopyrazolopyridine $4 \mathrm{a}-\mathrm{c}$.

Synthesis of 1-(4,6-Dimethyl-1H-pyrazolo[3,4b]-pyridin-3-ylazo)-2-(2-aminonaphthalen-6ylsulfonyl)ethanol 5

m.p. $>300^{\circ} \mathrm{C}$. Yield $=82 \%$. IR $\left(v / \mathrm{cm}^{-1}\right)$ : $3369\left(\mathrm{NH}_{2}\right), 3241(\mathrm{NH}), 1625 \mathrm{~cm}^{-1}(\mathrm{C}=\mathrm{N}), 1136$ $\left(-\mathrm{SO}_{2}\right) \cdot{ }^{1} \mathrm{H}$ NMR $\left(\mathrm{DMSO}_{6} \mathrm{~d}_{6}\right): \delta / \mathrm{ppm}=2.55(\mathrm{~s}$, $\left.3 \mathrm{H}, \mathrm{CH}_{3}\right), 2.66\left(\mathrm{~s}, 3 \mathrm{H}, \mathrm{CH}_{3}\right), 3.46-3.51(\mathrm{t}, 2 \mathrm{H},-$ $\left.\mathrm{CH}_{2} \mathrm{OH}\right), 3.68-3.71\left(\mathrm{t}, 2 \mathrm{H},-\mathrm{SO}_{2} \mathrm{CH}_{2}-\right), 4.92(1 \mathrm{H}$, $\mathrm{s}, \mathrm{OH}), 6.97\left(\mathrm{~s}, 1 \mathrm{H}\right.$, pyridine $\left.\mathrm{C}_{5}-\mathrm{H}\right), 7.31-8.86(\mathrm{~m}$, 5H, Ar-H), 8.89 (s, 2H, NH $), 13.65$ (s,1H NH). Analysis: $\mathrm{C}_{20} \mathrm{H}_{20} \mathrm{~N}_{6} \mathrm{O}_{3} \mathrm{~S}$ (424.48); Calcd. \%: C, 56.59; H, 4.75; N, 19.80; S, 7.55; Found \%: C, 56.32; H, 4.96; N, 19.64; S, 7.76

Synthesis of 3- (4,6-Dimethyl-1H-pyrazolo [3,4-b]-pyridin-3-ylazo)-2-naphthol 6

m.p. $>300^{\circ} \mathrm{C}$. Yield $=88 \%$. IR $\left(\mathrm{v} / \mathrm{cm}^{-1}\right): 3538$ $\mathrm{cm}^{-1}(\mathrm{OH}), 3280 \mathrm{~cm}^{-1}(\mathrm{NH}), 1612 \mathrm{~cm}^{-1}(\mathrm{C}=\mathrm{N})$. ${ }^{1} \mathrm{H}$ NMR (DMSO-d $)$ ): $\delta /$ ppm $2.55\left(\mathrm{~s}, 3 \mathrm{H}, \mathrm{CH}_{3}\right.$ ), $2.68\left(\mathrm{~s}, 3 \mathrm{H}, \mathrm{CH}_{3}\right), 6.97\left(\mathrm{~s}, 1 \mathrm{H}\right.$, pyridine $\left.\mathrm{C}_{5}-\mathrm{H}\right)$, 6.72-8.57 (m, 6H, naphthyl-H), $13.62(\mathrm{~s}, 1 \mathrm{H}$, $\mathrm{NH}$ ). Analysis: $\mathrm{C}_{18} \mathrm{H}_{15} \mathrm{~N}_{5} \mathrm{O}$ (317.34); Calcd. \%: C, 68.13; H, 4.76; N, 22.07; Found \%: C, 67.33; H, $5.05 ; \mathrm{N}, 22.48$

Synthesis of N,N-Diethyl-4-(4,6-dimethyl-1Hpyrazolo[3,4-b]pyridin-3-ylazo)aniline 7

m.p. $>300^{\circ} \mathrm{C}$. Yield $=88 \%$. IR $\left(\mathrm{v} / \mathrm{cm}^{-1}\right): 3130$ $\mathrm{cm}^{-1}(\mathrm{NH}), 2970,2928,2862,1430,1408,1351$ (C-H stretching and bending), $1601 \mathrm{~cm}^{-1}(\mathrm{C}=\mathrm{N})$. ${ }^{1} \mathrm{H}$ NMR (DMSO-d $)$ : $\delta / p p m ~ 1.14-1.21(\mathrm{t}, 6 \mathrm{H}, 2$ $\left.\times-\mathrm{CH}_{2} \mathrm{CH}_{3}\right), 2.54\left(\mathrm{~s}, 3 \mathrm{H}, \mathrm{CH}_{3}\right), 2.67\left(\mathrm{~s}, 3 \mathrm{H}, \mathrm{CH}_{3}\right)$, 3.35-3.60 (q, 4H, $\left.2 \times-\mathrm{CH}_{2} \mathrm{CH}_{3}\right), 6.97(\mathrm{~s}, 1 \mathrm{H}$, pyridine $\left.\mathrm{C}_{5}-\mathrm{H}\right), 6.79$ (d, 2H, J 8.6, Ar-H), 7.80 (d, $2 \mathrm{H}, \mathrm{Ar}-\mathrm{H}), 13.65$ (s, $1 \mathrm{H} \mathrm{NH})$. Analysis: $\mathrm{C}_{18} \mathrm{H}_{22} \mathrm{~N}_{6}$ (322.41); Calcd. \%: C, 67.06; H, 6.88; N, 26.07; Found \%: C, 67.81; H, 7.02; N, 25.48 
Synthesis of 3-(4,6-dimethyl-1H-pyrazolo[3,4-b] pyridin-3-ylazo)-2-naphylamine 8

m.p. $>300^{\circ} \mathrm{C}$. Yield $=88 \%$. IR $\left(v / \mathrm{cm}^{-1}\right): 3395$, $3315\left(\mathrm{NH}_{2}\right), 3144(\mathrm{NH}), 1601 \mathrm{~cm}^{-1}(\mathrm{C}=\mathrm{N}) \cdot{ }^{1} \mathrm{H}$ NMR $\left.(\text { DMSO-d })_{6}\right): \delta / p p m=2.55\left(\mathrm{~s}, 3 \mathrm{H}, \mathrm{CH}_{3}\right)$, $2.68\left(\mathrm{~s}, 3 \mathrm{H}, \mathrm{CH}_{3}\right), 6.97\left(\mathrm{~s}, 1 \mathrm{H}\right.$, pyridine $\left.\mathrm{C}_{5}-\mathrm{H}\right)$, 7.13-8.65 (m, 6H, naphthyl-H), $8.85\left(\mathrm{~s}, 2 \mathrm{H}, \mathrm{NH}_{2}\right)$, $13.62(\mathrm{~s}, 1 \mathrm{H}, \mathrm{NH})$. Analysis: $\mathrm{C}_{18} \mathrm{H}_{16} \mathrm{~N}_{6}(316.36)$; Calcd. \%: C, 68.34; H, 5.10; N, 26.56; Found \%: C, $67.50 ; \mathrm{H}, 4.91 ; \mathrm{N}, 25.81$

Synthesis of N-ethyl-N-benzyl-4-(4,6-dimethyl1H-pyrazolo[3,4-b]pyridin-3-ylazo)aniline 9

m.p. $>300^{\circ} \mathrm{C}$. Yield $=88 \%$. IR $\left(\mathrm{v} / \mathrm{cm}^{-1}\right)$ : $3112(\mathrm{NH}), 2967,2928,2871,1425,1393$, 1352 (C-H stretching and bending), $1601 \mathrm{~cm}^{-1}$ $(\mathrm{C}=\mathrm{N}) .{ }^{1} \mathrm{H}$ NMR $\left(\right.$ DMSO-d $\left._{6}\right): \delta / \mathrm{ppm}$ 1.15-1.22 $\left(\mathrm{t}, 3 \mathrm{H},-\mathrm{CH}_{2} \mathrm{CH}_{3}\right), 2.53\left(\mathrm{~s}, 3 \mathrm{H}, \mathrm{CH}_{3}\right), 2.67$ (s, $\left.3 \mathrm{H}, \mathrm{CH}_{3}\right), 3.35-3.61$ (q, $2 \mathrm{H},-\mathrm{CH}_{2} \mathrm{CH}_{3}$ ), 4.68 (s, $\left.2 \mathrm{H},-\mathrm{CH}_{2} \mathrm{Ph}\right), 6.97\left(\mathrm{~s}, 1 \mathrm{H}\right.$, pyridine $\left.\mathrm{C}_{5}-\mathrm{H}\right), 6.81-$ 7.80 (m, 9H, Ar-H), 13.70 (s, 1H, NH). Analysis: $\mathrm{C}_{18} \mathrm{H}_{16} \mathrm{~N}_{6}$ (316.36); Calcd. \%: C, 71.85; H, 6.29; N, 21.86; Found \%: C, 70.15; H, 5.96; N, 20.65

\section{Results and Discussion}

Chemistry of synthesis and characterization

The increasing importance of 3-aminopyrazolo [3,4-b]pyridine as an adaptable intermediate for the preparation of numerous fused heterocyclic rings as drugs for various pharmaceutical purposes led to the ongoing growth of novel uncomplicated procedures for their production [6-12]. In continuation of the preparation of nitrogen-containing heterocyclic structures, it was found that diazotized heterocyclic-containing amine can be considered as an excellent building unit for the production of the intended compound. Thus, azo-coupling of the pyrazolopyridinyl diazonium salt 2 with a variety of coupling agents including $\beta$-naphthylamine, $\beta$-naphthol, thiazole, and aniline derivatives afforded the corresponding arylazopyrazolo[3,4-b]pyridines $5-9$. The chemical structure of compound 5 was demonstrated accordring to its analytical and spectral data. The FT-IR spectrum displayed stretching frequencies of two peaks at 3395, $3315 \mathrm{~cm}^{-1}$ assigned to $\mathrm{NH}_{2}$ group, $3144 \mathrm{~cm}^{-1}$ for $\mathrm{NH}, 1601 \mathrm{~cm}^{-1}$ for $\mathrm{C}=\mathrm{N}$. The ${ }^{1} \mathrm{H}-\mathrm{NMR}$ spectrum in deuterated DMSO displayed two singlet peaks at 2.55 and $2.86 \mathrm{ppm}$ assigned to the two methyl protons, singlet peak at $6.97 \mathrm{ppm}$ for pyridine $\mathrm{C} 5-\mathrm{H}$ proton and multiplet peak at 7.13-8.65 ppm for the aromatic ring protons. By considering the above data in addition to $(\mathrm{C}, \mathrm{H}, \mathrm{N})$ elemental analysis, this reaction product could be formulated as the 4,6dimethyl-1H-pyrazolo [3,4-b]pyridine derivative while azo coupling of the pyrazolopyridinyl diazonium salt 2 with another coupling agent such as $\mathrm{N}, \mathrm{N}$-diethylamine gave $\mathrm{N}, \mathrm{N}$ - Diethyl -4-(4,6- dimethyl -1H-pyrazolo[3,4-b]pyridin3 -ylazo)aniline 7 . The chemical structure of arylazopyrazolo[3,4-b]pyridine 7 is proved by both of analytical and spectral techniques. FTIR demonstrated peak with one spike $3130 \mathrm{~cm}^{-1}$ $(\mathrm{NH}), 2970,2928,2862,1430,1408,1351(\mathrm{C}-\mathrm{H}$ stretching and bending), $1601 \mathrm{~cm}^{-1}(\mathrm{C}=\mathrm{N})$. The ${ }^{1} \mathrm{H}$-NMR spectrum in deuterated DMSO as a solvent showed two triplet peaks at $1.14,1.12 \mathrm{ppm}$ and two quartet peaks at $3.35,3.6 \mathrm{ppm}$ for two ethyl groups. The reaction of the pyrazolopyridinyl diazonium salt 2 with N-ethyl-N-benzylpyrazolopyridine affords N-ethyl -N- benzyl-4-(4,6dimethyl-1H-pyrazolo[3,4-b]pyridin-3-ylazo) aniline 9 is assigned by its analytical and spectral data. ${ }^{1} \mathrm{H}-\mathrm{NMR}$ in deuterated DMSO shows a triplet at $1.15-1.22 \mathrm{ppm}$ for $3 \mathrm{H}$, and $3.35-3.61$ ppm for $2 \mathrm{H}$ of $\left(-\mathrm{CH}_{2} \mathrm{CH}_{3}\right)$, and two singlet peaks at 2.53 and $2.67 \mathrm{ppm}$ for two methyl groups on pyridine ring, a quartet peak for ethyl group at 3.35-3.61 ppm, singlet peak at $4.68 \mathrm{ppm}$ for $\mathrm{CH}_{2} \mathrm{Ph}$ the higher value of chemical shift due to withdrawal effect of phenyl ring), also aromatic protons appears at $6.97 \mathrm{ppm}$ singlet $1 \mathrm{H}$, of pyridine $\mathrm{C}_{5}-\mathrm{H}$, multiplet at $6.81-7.80 \mathrm{ppm}$ for $9 \mathrm{H}$, Ar-H, finally singlet at $13.70 \mathrm{ppm}$ for $1 \mathrm{H}$ of $(\mathrm{NH})$. The synthetic procedures to achieve the target pyrazolo[3,4-b]pyridine derivatives are described in Scheme 1.

\section{Dyeing performance}

Our azo dyes can be considered as dispersetype dyes able to potentially dye hydrophobic polyester fibers because they can be recognized as non-ionic small molecules with low solubility in water. They are applied to dye polyester fibers at $130^{\circ} \mathrm{C}$ and $2 \%$ shade utilizing the high temperature pressure dyeing technique [16]. The color shades varied from orange-red to red. All dyestuffs 4a-c and 5-9 displayed good color strength and acceptable fastness properties (Table 1). 
<smiles>CC(=O)CC(C)=O</smiles><smiles>[R]N=Nc1n[nH]c2nc(C)cc(C)c12</smiles><smiles>[R]=Cc1sc(N)nc1-c1ccccc1</smiles><smiles>[Z6][Z6]1(C)sc(NC)nc1-c1ccccc1</smiles><smiles>[Y]c1sc(Nc2ccccc2)nc1-c1ccccc1</smiles><smiles>CCN(CC)c1ccc(S)c(I)c1</smiles><smiles>CCN(Cc1ccccc1)c1ccc(F)cc1</smiles><smiles>Nc1ccc2cc(S(=O)(=O)CCO)ccc2c1[As]</smiles><smiles>Nc1cc2ccccc2cc1S</smiles>

Scheme 1. Synthetic approach of pyrazolo $[3,4-b]$ pyridine. 
TABLE 1. Color strength and fastness properties of dyes 4a-c and 5-9 on polyester garments.

\begin{tabular}{|c|c|c|c|c|c|c|c|c|c|c|c|c|}
\hline \multirow{3}{*}{$\begin{array}{l}\text { Dye } \\
\text { No. }\end{array}$} & \multirow{3}{*}{$\begin{array}{c}\lambda_{\max } \\
(\mathrm{nm})\end{array}$} & \multirow{3}{*}{$\mathbf{K} / \mathbf{S}$} & \multirow{3}{*}{ Shade } & \multicolumn{2}{|c|}{ Wash } & \multicolumn{4}{|c|}{ Perspiration } & \multicolumn{2}{|c|}{ Rubbing } & \multirow{3}{*}{ Light $^{* *}$} \\
\hline & & & & \multirow{2}{*}{ Alt.* } & \multirow{2}{*}{ St.* } & \multicolumn{2}{|c|}{ Acidic } & \multicolumn{2}{|c|}{ Basic } & \multirow{2}{*}{ Dry } & \multirow{2}{*}{ Wet } & \\
\hline & & & & & & Alt.* & St. $^{*}$ & Alt.* & St. ${ }^{*}$ & & & \\
\hline $4 a$ & 481 & 3.60 & Red & $3-4$ & 4 & 4 & 4 & 4 & 4 & 4 & 4 & 6 \\
\hline $4 b$ & 477 & 4.29 & Red & 4 & $4-5$ & 4 & 4 & 4 & $4-5$ & 4 & 4 & $5-6$ \\
\hline $4 c$ & 470 & 4.83 & Red & $3-4$ & 4 & 4 & 4 & 4 & 4 & 4 & 4 & $5-6$ \\
\hline 5 & 478 & 7.11 & Orange-red & 4 & $4-5$ & $3-4$ & 3 & $3-4$ & 4 & 4 & $3-4$ & $5-6$ \\
\hline 6 & 465 & 3.89 & Orange-red & $3-4$ & $3-4$ & 4 & 4 & $3-4$ & 4 & 4 & 4 & $6-7$ \\
\hline 7 & 483 & 4.63 & Orange-red & 4 & 4 & $3-4$ & $4-5$ & 4 & 4 & 4 & $3-4$ & 6 \\
\hline 8 & 496 & 6.47 & Orange-red & 4 & 4 & 4 & 4 & 4 & 4 & 4 & $3-4$ & $5-6$ \\
\hline 9 & 489 & 4.26 & Orange-red & 4 & 4 & 4 & $3-4$ & 4 & 4 & 4 & 4 & $6-7$ \\
\hline
\end{tabular}

${ }^{*}$ Alt. $=$ alteration in color; St. $=$ staining on cotton.

\section{Conclusion}

In conclusion, we could show that a series of azo-pyrazolopyridine disperse dyestuffs have been synthesized. The key starting fused heterocyclic compound 3-aminopyrazolo[3,4-b] pyridine is prepared by the reaction of 2-chloro3,6-dimethylnicotinonitrile with hydrazine hydrate. The azo-coupling reaction of the pyrazolopyridinyl diazonium salt afforded the corresponding arylazopyrazolo[3,4-b]pyridine derivatives in relatively high yield. The produced arylazopyrazolo[3,4- $b]$ pyridine dyestuffs were applied on polyester samples via high temperature pressure dyeing technique to provide solid shades with acceptable color constancy and deepness. The shades occurred between orange-red and red. The color fastness properties displayed mostly good fastness against light, rubbing, perspiration and washing.

\section{Acknowledgements}

Technical support from Textile Research Division, National Research Centre, Cairo, Egypt; is gratefully acknowledged.

\section{References}

1. Zhang B. and Studer A., Recent advances in the synthesis of nitrogen heterocycles via radical cascade reactions using isonitriles as radical acceptors. Chemical Society Reviews, 44, 35053521 (2015).

2. Khattab T.A., Haggag K.M., Elnagdi M.H., Abdelrahman A.A. and Aly S.A., Microwaveassisted synthesis of arylazoaminopyrazoles as disperse dyes for textile printing. Zeitschrift Für
Anorganische Und Allgemeine Chemie, 642, 766772 (2016).

3. Ng V.W.L., Tan J.P.K., Leong J., Voo Z.X., Hedrick J.L. and Yang Y.Y., Antimicrobial polycarbonates: Investigating the impact of nitrogen-containing heterocycles as quaternizing agents. Macromolecules, 47, 1285-1291 (2014).

4. Majumdar P., Pati A., Patra M., Behera R.K. and Behera A.K., Acid hydrazides, potent reagents for synthesis of oxygen-, nitrogen-, and/or sulfurcontaining heterocyclic rings. Chemical Reviews, 114, 2942-2977 (2014).

5. Khattab T.A., Elnagdi M.H., Haggag K.M., Abdelrahman A.A. and Aly S.A., Green synthesis, printing performance, and antibacterial activity of disperse dyes incorporating arylazopyrazolopyrimidines. AATCC Journal of Research, 4, 1-8 (2017).

6. Menezes C.M.S., Sant'Anna C.M.R., Rodrigues,C.R. and Barreiro E.J., Molecular modeling of novel $1 \mathrm{H}-$ pyrazolo[3, 4- $b]$ pyridine derivatives designed as isosters of the antimalarial mefloquine. Journal of Molecular Structure: THEOCHEM, 579, 31-39 (2002).

7. Lin R., Connolly P.J., Lu Y., Chiu G., Li S., Yu Y. and Huang S., Synthesis and evaluation of pyrazolo [3, 4-b] pyridine CDK1 inhibitors as anti-tumor agents. Bioorganic \& Medicinal Chemistry Letters, 17, 4297-4302 (2007).

8. Frolova L.V., Malik I., Uglinski, P.Y., Rogelj S., Kornienko A. and Magedov I.V., Multicomponent synthesis of 2, 3-dihydrochromeno [4, 3- $d]$ pyrazolo $[3,4-b]$ pyridine-1, 6-diones: a novel heterocyclic 
scaffold with antibacterial activity. Tetrahedron Letters, 52, 6643-6645 (2011).

9. Misra R.N., Kimball S.D., Rawlins D.B., Webster K.R. and Bursuker I., Use of pyrazolo[3, 4-b] pyridine as cyclin dependent kinase inhibitors. U.S. Patent 6,107,305, 2000.

10. Cappelli A., Nannicini C., Gallelli A., Giuliani G., Valenti S., Mohr G.P. and Anzini M., Design, synthesis, and biological evaluation of AT1 angiotensin II receptor antagonists based on the pyrazolo[3, 4- $b]$ pyridine and related heteroaromatic bicyclic systems. Journal Of Medicinal Chemistry, 51, 2137-2146 (2008).

11. Bernardino A.M.R., de Azevedo A.R., da Silva Pinheiro L.C., Borges J.C., Carvalho V.L., Miranda M.D. and de Meneses M.D.F., Synthesis and antiviral activity of new 4-(phenylamino)/4[(methylpyridin-2-yl) amino]-1-phenyl-1Hpyrazolo[3, 4- $b]$ pyridine-4-carboxylic acids derivatives. Medicinal Chemistry Research, 16, 352-369 (2007).

12. Bernardino A.M., Rolim, da Silva Pinheiro L.C., Rodrigues C.R., Loureiro N.I., Castro H.C., Lanfredi-Rangel A. and Sabatini-Lopes J., Design, synthesis, SAR, and biological evaluation of new 4-(phenylamino) thieno[2, 3-b]pyridine derivatives. Bioorganic \& Medicinal Chemistry, 14, 5765-5770 (2006).

13. Abu-Melha S., Synthesis and antimicrobial activity of some new heterocycles incorporating the pyrazolopyridine moiety. Archiv der Pharmazie, 346, 912-921 (2013).

14. Khan M.F., Alam M.M., Verma G., Akhtar W., Akhter M. and Shaquiquzzaman M., The therapeutic voyage of pyrazole and its analogs: a review. European Journal Of Medicinal Chemistry, 120, 170-201 (2016).

15. Abulwerdi F.A., Mady A.S.A., Perdih A., Stuckey J.A., Showalter H.D. and Nikolovska-Coleska Z., Structure-based design and development of pyrazolopyridine-based inhibitors of Mcl-1. 1641-
1641 (2014).

16. Kulkarni S.V., Blackwell C.D., Blackard A.L., Stackhouse C.W. and Alexander M.W., Textile dyeing operations-chemistry, equipment, procedures, and environmental aspects. Noyes Publications (1986).

17. ISO 105-C02:1989 Textiles: Tests for color fastness, Part C02: Color fastness to washing: Test 2 (Basel: ISO, 1989).

18. ISO 105-X12:1987 Textiles: Tests for color fastness, Part X12: Color fastness to rubbing (Basel: ISO, 1987).

19. ISO 105-E04:1989 Textiles: Tests for color fastness, Part E04: Color fastness to perspiration (Basel: ISO, 1989).

20. ISO 105-B02:1988 Textiles: Tests for color fastness, Part B02: Color fastness to artificial light: Xenon arc fading lamp test (Basel: ISO, 1988).

21. Baumann W., Kleinemeier N., Brossman R., Oesch H.P., Krayer M., Groebel B.T. and Leaver A.T., Determination of relative colour strength and residual colour difference by means of reflectance measurements. Journal of the Society of Dyers and Colourists, 103, 100-105 (1987).

22. Teli M.D. and Prasad N.M., Effect of heat setting and dyeing temperatures on dyeability/t enacity of cationic-dyeable and normal polyester. American Dyestuff Reporter, 38-42 (1991).

23. Teli M.D. and Nayak A.K., Evaluating the disperse dyeability of polyester in fabric form: Part I. American Dyestuff Reporter, 83, 36-43 (1994).

24. Lacan M. and Tabakovic K., Synthesis of new pyrazolo-and tetrazolopyridines. ChemInform, 7, (1976).

25. Huang Z.-T. and Shi X., Synthesis of heterocyclic ketene $\mathrm{n}$, s-acetals and their reactions with esters of $\alpha, \beta$-unsaturated acids. Synthesis, 1990, 162-167 (1990).

(Received 13/8/2017; accepted 15/10/2017) 


\section{تحضير وتوصيف بعض مركبات الازو الحلقية الغير متجانسة التي تحتوي علي وحدة

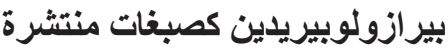

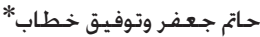

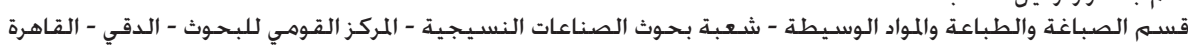

يهدف هذا البحث الي تحضير مركبات الاريل ازو بير ازولوبيريدين باستخدام مركبات -3امينو بير ازولوبيريدين

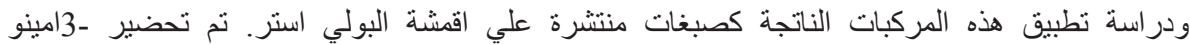

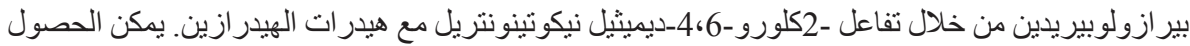

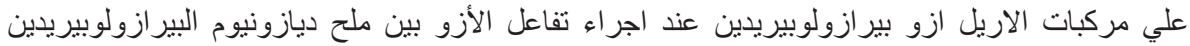

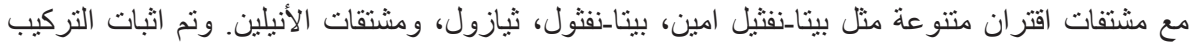

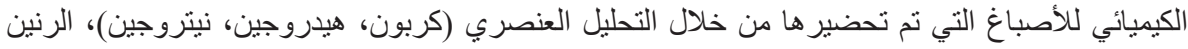

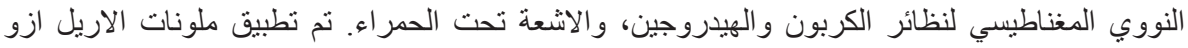

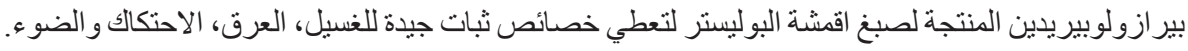

